\title{
GMR
}

\section{Targeting effect of microRNA on $C D 133$ and its impact analysis on proliferation and invasion of glioma cells}

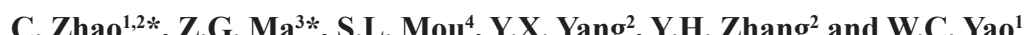

${ }^{1}$ Department of Neurosurgery, The Affiliated Hospital of Qingdao University, Qingdao, Shandong, China

2Department of Neurosurgery, The People's Hospital of Rizhao, Rizhao, Shandong, China

${ }^{3}$ Department of Neurosurgery, Fifth Hospital of PLA, Yinchuan, Ningxia, China ${ }^{4}$ Department of Laboratory, The People's Hospital of Rizhao, Rizhao,

Shandong, China

*These authors contributed equally to this study.

Corresponding author: W.C. Yao

E-mail: guangmingxu220@sina.com

Genet. Mol. Res. 16 (1): gmr16019281

Received September 14, 2016

Accepted December 14, 2016

Published March 30, 2017

DOI http://dx.doi.org/10.4238/gmr16019281

Copyright $(\underset{2}{ } 2017$ The Authors. This is an open-access article distributed under the terms of the Creative Commons Attribution ShareAlike (CC BY-SA) 4.0 License.

ABSTRACT. MiR-200b, a member of the microRNA-200 family, has been identified to be capable of suppressing glioma cell growth through targeting CREB1 or CD133. However, whether miR-200b affects the biological behavior (proliferation, invasion, and migration) of glioma cells is poorly understood. The aim of this study was to evaluate the effect of miR-200b on the biological behavior of glioma cells in vitro. MiRNA-200b mimics, miRNA-200b inhibitor, and mimic control were transfected into conventionally cultured glioma U251 cells, followed by measuring the expression of miR-200b and CD133 in transfected cells by RT-PCR; effect of miR-200b on CD133 mRNA 3'-UTR luciferase activity by luciferase reporter assay; proliferation activity of transfected

Genetics and Molecular Research 16 (1): gmr16019281 
U251 cells by MTT method; and changes in U251 cell invasion and migration by Transwell method after transfection. Compared to that in the miRNA-200b inhibitor, mimic control, and blank control groups, miRNA-200b expression was significantly increased and CD133 mRNA expression was significantly decreased in the mimic miRNA$200 \mathrm{~b}$ group in a time-dependent manner $(\mathrm{P}<0.05)$. Meanwhile, dual luciferase reporter assay showed that miR-200b could inhibit $C D 133$ activity through binding to the 3 '-UTR of CD133 mRNA $(\mathrm{P}<0.05)$. Furthermore, the proliferation activity and invasion and migration abilities of U251 cells transfected with miRNA-200b mimic were significantly decreased $(\mathrm{P}<0.05)$. In conclusion, overexpression of miR-200b inhibited the proliferation, invasion, and migration of glioma cells possibly through targeting $C D 133$.

Key words: miR-200b; CD133; Glioblastoma U251 cells; Proliferation; Invasion; Migration

\section{INTRODUCTION}

Glioma is the most common type of malignant tumor of the nervous system with a WHO classification of grade I-IV. The postoperative recurrence rate is still very high along with a poor prognosis and decreased short- and long-term survival times (Wu et al., 2011). The mean survival time of patients with malignant gliomas was only 14 months with the 5-year survival rate being less than 5\% (Tabatabai and Weller, 2011). Previous studies have demonstrated that activation of proto-oncogenes and inactivation of tumor suppressor genes may induce malignant tumor cells to escape regulation, leading to uncontrolled proliferation and ultimately resulting in the development of glioma (Lei and Canoll, 2011).

MicroRNAs (miRNAs) are small non-coding RNA molecules containing a hairpin loop structure with a length of about 16-24 nucleotides, which has a strong regulatory effect on gene expression (Yamamoto et al., 2008). MiRNAs are involved in the occurrence and development of cancers through regulation of the growth and development of cells (Brandsma et al., 2008; Li et al., 2016; Wang et al., 2016). The expression of miR-200b, a member of the microRNA-200 family, has been found to be decreased in various tumor tissues and cells and capable of inhibiting the proliferation and growth of glioma cells through targeting CREB1 or CD133 (Mongroo and Rustgi, 2010; Zhao et al., 2014). However, whether miR-200b affects the biological behavior (proliferation, invasion, and migration) of glioma cells is poorly understood. The aim of this study was to evaluate the role of miR-200b in the biological behavior of glioma cells in vitro after transfection with miR-200b mimic or inhibitor.

\section{MATERIAL AND METHODS}

\section{Test cells, reagents, and instruments}

miRNA-200b, $C D 133$, $\beta$-actin, and RT-PCR reagent kit were purchased from Takara Shuzo (Kyoto, Japan); PCR amplification instrument PTC-100, from PerkinElmer, Inc. (Waltham, MA, USA); TRIzol reagent, from Gibco (Thermo Fisher Scientific, Waltham, MA,

Genetics and Molecular Research 16 (1): gmr16019281 
USA); RPMI-1640 culture medium and MTT, from Sigma-Aldrich (St. Louis, MO, USA); and carbon dioxide incubator and inverted microscope, from Sanyo (Osaka, Japan).

\section{Experimental methods}

\section{Cell transfection}

Human malignant glioma cell line U251 (Qingdao University, Shandong, China) was cultured in Dulbecco's modified Eagle's medium containing 10\% fetal bovine serum and 100 $\mathrm{U} / \mathrm{mL}$ penicillin and streptomycin (Gibco) at $37^{\circ} \mathrm{C}$ with $5 \% \mathrm{CO}_{2}$. Tumor cells were seeded in the cell culture plate, and when the cell growth rate reached about $60 \%$ confluence, miRNA$200 \mathrm{~b}$ mimics, miRNA-200b inhibitor, and mimic control (GenePharma, Shanghai, China) were transfected into U251 cells using Lipofectamine 2000 (Invitrogen, Thermo Fisher Scientific). After 4-6 h, the medium was replaced. The cells were cultured for $48 \mathrm{~h}$. Non-transfected U251 cells constituted the blank control group.

\section{Detection of miRNA-200b and CD133 expression by RT-PCR in the transfected U251 cell strain}

U251 cells were transfected with miRNA-200b mimics, miRNA-200b inhibitor, and mimic control for $72 \mathrm{~h}$. Total RNA extraction was performed according to the manufacturer's instructions of TRIzol reagent. The concentration of total RNA was determined to calculate the OD260/280 ratio. Total RNA (200 ng) was extracted and the polyA tail of miRNA was synthesized, followed by cDNA synthesis according to the kit manufacturer's instructions (Takara Shuzo). PCR amplification was performed. Table 1 lists the primer sequences designed for the amplification process. PCR conditions were as follows: first step: $95^{\circ} \mathrm{C}, 30 \mathrm{~s}$, and second step (for 40 amplification cycles): $95^{\circ} \mathrm{C}, 5 \mathrm{~s}$ and $60^{\circ} \mathrm{C}, 30 \mathrm{~s}$. U6 was used as the internal reference gene because of its stable expression. The relative mRNA expression of target genes (normalized as a ratio to $U 6$ ) was calculated by the comparative $\mathrm{Ct}$ method using the following formula: relative expression $=2^{-\Delta \Delta C t}$.

\begin{tabular}{|c|c|c|}
\hline Gene & & Sequences $\left(5^{\prime}-3^{\prime}\right)$ \\
\hline \multirow{2}{*}{ miRNA-200b } & Upstream & 5'-AGCCGTCAAGAGCAATAACGAA-3' \\
\hline & Downstream & 5'-GTGCAGGGTCCGAGGT-3' \\
\hline \multirow[t]{2}{*}{ CD133 } & Upstream & 5'-TGGTGGGCAGTATGTTGT-3' \\
\hline & Downstream & 5'-GCTATTGGCATTGGTGAA-3' \\
\hline \multirow[t]{2}{*}{ U6 } & Upstream & 5'-CTCGCTTCGGCAGCACA-3' \\
\hline & Downstream & 5'-AACGCTTCACGAATTTGCGT-3' \\
\hline
\end{tabular}

\section{Luciferase reporter assay}

Genomic DNA containing miRNA-509-5p binding sites in the 3'-UTR of CD133 was amplified. The control vector was inserted, and the control vector carrying mutated CD133 $3^{\prime}$-UTR was regarded as the control. MiRNA-200b was co-transfected using Lipofectamine 2000 as per the manufacturer's instructions. After $24 \mathrm{~h}$ of U251 cell transfection, results were detected by the dual luciferase reporter gene assay.

Genetics and Molecular Research 16 (1): gmr16019281 


\section{Detection of the proliferation activity of transfected HGC-27 cells}

The cells transfected with miRNA-200b mimics, miRNA-200b inhibitor, and mimic control and the blank control group in the logarithmic phase of growth were collected in suspension. The suspension concentration was adjusted to $8 \times 10^{4}$ cells/ well and incubated at $37^{\circ} \mathrm{C}$ with $5 \% \mathrm{CO}_{2}$. After 24,48 , and $72 \mathrm{~h}$, proliferation activity of the cells was measured. MTT solution $(20 \mu \mathrm{L} 5 \mathrm{mg} / \mathrm{mL}$ concentration) was added to the cells, which were incubated for $4 \mathrm{~h}$, followed by addition of $150 \mu \mathrm{L}$ dimethyl sulfoxide and shaking of the mixture for $10 \mathrm{~min}$. Absorbance was measured at $570 \mathrm{~nm}$. The growth curve was prepared by plotting the absorbance values (Y-axis) against time (X-axis).

\section{Detection of invasion and migration of $U 251$ cells by the Transwell method after transfection}

Invasion experiment: Matrigel was added into the Transwell chamber, and the chamber was kept overnight at $4{ }^{\circ} \mathrm{C}$. Cells were added to serum-free water and incubated at $37^{\circ} \mathrm{C}$ for $1 \mathrm{~h}$. After transfection, the cells were seeded into the upper compartment of the Transwell chamber, and RPMI-1640 culture medium was added to the lower compartment. Giemsa staining was then performed to observe and enumerate the cells using an inverted microscope.

Migration experiment: This experiment was similar to the invasion experiment. Cells were seeded into the chamber; however, this method needed an artificial basement membrane.

\section{Data processing}

The SPSS 17.0 statistics software was used for data processing. Data are reported as means \pm standard deviation. The two-way ANOVA was used for comparison of the expression levels of miRNA-200b and CD133 and reporting the proliferation activity of the U251 cell strain after transfection with the different groups over time. Unpaired Student $t$-test was performed to compare the luciferase activity of U251 cells between control and transfected cells. $\mathrm{P}<0.05$ was considered as statistically significant.

\section{RESULTS}

\section{Expression of miRNA-200b and $C D 133$ in U251 cell strain after transfection}

The concentration of extracted RNA was $500 \mathrm{mg} / \mathrm{mL}$ (in a total volume of $50 \mu \mathrm{L}$ ) with an OD260/280 ratio of 1.9. The expression of miRNA-200b and CD133 in U251 cells after transfection were detected by RT-PCR. Compared to that in the miRNA-200b inhibitor, mimic control, and control groups, we observed that miRNA-200b expression was significantly increased in the miRNA-200b mimic group, while CD133 mRNA expression was decreased in a time-dependent manner $(\mathrm{P}<0.05)$ (Table 2). However, in the miRNA-200b inhibitor group, miRNA-200b expression was significantly decreased and $C D 133$ mRNA expression was increased in a time-dependent manner $(\mathrm{P}<0.05)$ (Table 2). 
Table 2. Expression of miRNA-200b and CD133 in the U251 cells after transfection.

\begin{tabular}{l|c|c|c|c}
\hline Incubation period & miRNA-200b mimic & miRNA-200b inhibitor & Mimic control & Blank control \\
\hline miRNA-200b & & & & \\
\hline $24 \mathrm{~h}$ & $1.102 \pm 0.014^{\mathrm{abc}}$ & $0.232 \pm 0.017^{\mathrm{bc}}$ & $0.703 \pm 0.010$ & $0.765 \pm 0.011$ \\
\hline $48 \mathrm{~h}$ & $1.547 \pm 0.045^{\mathrm{abcd}}$ & $0.058 \pm 0.009^{\mathrm{bcd}}$ & $0.697 \pm 0.011$ & $0.744 \pm 0.012$ \\
\hline $72 \mathrm{~h}$ & $1.972 \pm 0.063^{\text {abcde }}$ & $0.031 \pm 0.001^{\mathrm{bcde}}$ & $0.656 \pm 0.012$ & \\
\hline$C D 133 \mathrm{mRNA}$ & & & & $1.758 \pm 0.009$ \\
\hline $24 \mathrm{~h}$ & $1.124 \pm 0.023^{\mathrm{abc}}$ & $1.174 \pm 0.036^{\mathrm{bc}}$ & $1.133 \pm 0.025$ & $1.151 \pm 0.031$ \\
\hline $48 \mathrm{~h}$ & $0.732 \pm 0.013^{\mathrm{abcd}}$ & $1.561 \pm 0.065^{\mathrm{bcd}}$ & $1.141 \pm 0.017$ & $1.154 \pm 0.028$ \\
\hline $72 \mathrm{~h}$ & $0.304 \pm 0.005^{\text {abcde }}$ & $1.932 \pm 0.087^{\mathrm{bcde}}$ & $1.138 \pm 0.022$ & $1.157 \pm 0.027$ \\
\hline
\end{tabular}

${ }^{\mathrm{a} C}$ Compared with the miRNA-200b inhibitor group, the difference was statistically significant, $\mathrm{P}<0.05$; ${ }^{\mathrm{b}}$ compared with the mimic control, the difference was statistically significant, $\mathrm{P}<0.05$; ${ }^{\circ}$ compared with the blank control, the difference was statistically significant, $\mathrm{P}<0.05$; ${ }^{\mathrm{d}}$ compared with the $24 \mathrm{~h}$ incubation period, the difference was statistically significant, $\mathrm{P}<0.05$; ${ }^{\mathrm{e}}$ compared with the $48 \mathrm{~h}$ incubation period, the difference was statistically significant, $\mathrm{P}<0.05$.

\section{Targeting effect of miRNA-200b on CD133 3'-UTR}

The luciferase reporter assay results showed that the luciferase activity of U251 cells was decreased with a statistically significant difference after co-transfection of the 3'-UTR of CD133 and miRNA-200b mimic $(\mathrm{P}<0.05)$ (Figure 1). Then, the binding site of 3'-UTR of CD133 and miRNA-200b was mutated and transfected into U251 cells. As shown in Figure 1 , luciferase activity increased after mutation since the mutation inhibited the binding of miRNA-200b and the 3'-UTR of CD133.

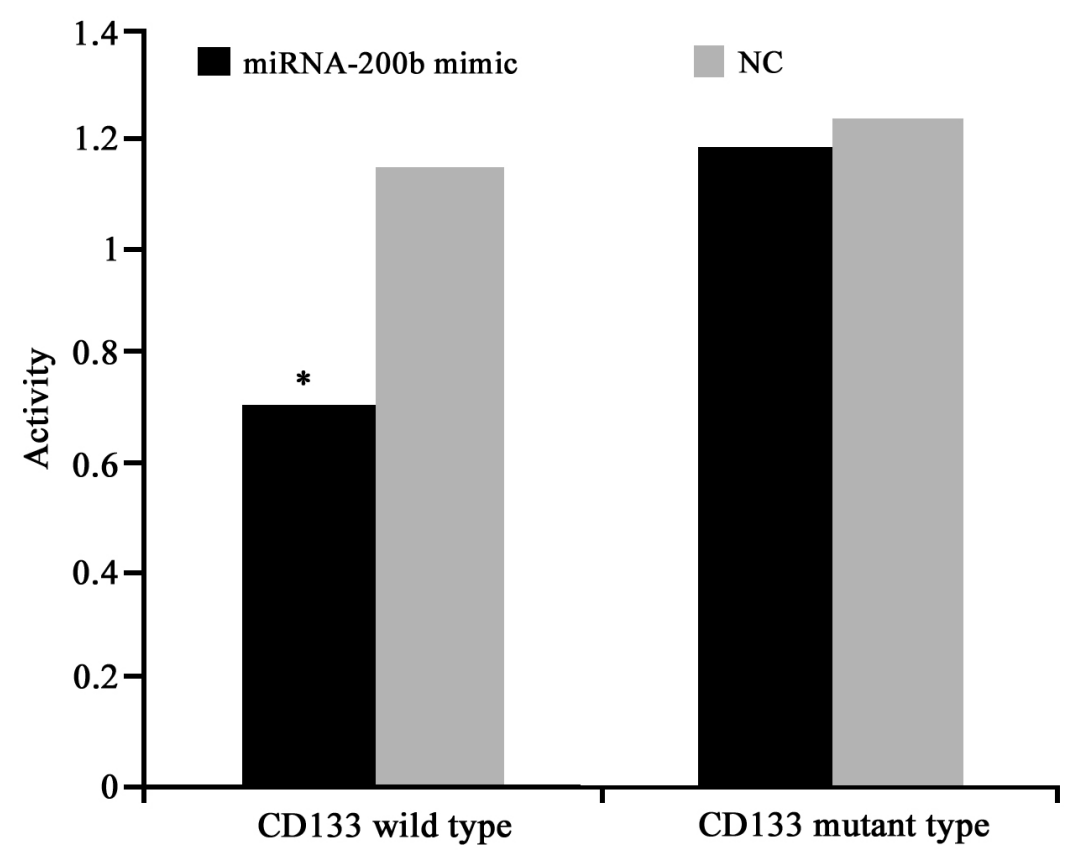

Figure 1. Targeting effect of miRNA-200b on the 3'-UTR of CD133. *Compared with the control group, the difference was statistically significant $(\mathrm{P}<0.05)$.

Genetics and Molecular Research 16 (1): gmr16019281 


\section{Detection of the proliferation activity of U251 cells by MTT after transfection}

The proliferation activity of U251 cells was detected by MTT after transfection. Compared to those of the miRNA-200b inhibitor, mimic control, and blank control groups, the OD value and proliferation ratio of the miRNA-200b mimic group were significantly decreased. However, the OD values and proliferation ratios of the miRNA-509-5p inhibitor, mimic control, and blank control groups increased gradually and had statistically significant values $(\mathrm{P}<0.05)$ (Table 3$)$.

\begin{tabular}{|c|c|c|c|c|}
\hline Incubation period & miRNA-200b mimic & miRNA-200b inhibitor & Mimic control & Blank control \\
\hline \multicolumn{5}{|l|}{ OD value } \\
\hline $24 \mathrm{~h}$ & $0.781 \pm 0.043^{\mathrm{abc}}$ & $1.029 \pm 0.018^{\mathrm{bc}}$ & $1.010 \pm 0.012$ & $1.009 \pm 0.016$ \\
\hline $48 \mathrm{~h}$ & $0.421 \pm 0.021^{\mathrm{abcd}}$ & $1.273 \pm 0.024^{\text {bcd }}$ & $1.125 \pm 0.027^{\mathrm{d}}$ & $1.135 \pm 0.024^{\mathrm{d}}$ \\
\hline $72 \mathrm{~h}$ & $0.231 \pm 0.011^{\text {abcde }}$ & $1.424 \pm 0.055^{\text {bcde }}$ & $1.174 \pm 0.038^{\mathrm{de}}$ & $1.181 \pm 0.031^{\mathrm{de}}$ \\
\hline \multicolumn{5}{|c|}{ Proliferation ratio (\%) } \\
\hline $24 \mathrm{~h}$ & $109^{\mathrm{abc}}$ & $128^{\mathrm{bc}}$ & 123 & 120 \\
\hline $48 \mathrm{~h}$ & $82^{\mathrm{abcd}}$ & $149^{\mathrm{bcd}}$ & $137^{\mathrm{d}}$ & $138^{\mathrm{d}}$ \\
\hline $72 \mathrm{~h}$ & $68^{\text {abcde }}$ & $167^{\text {bcde }}$ & $153^{\mathrm{de}}$ & $156^{\mathrm{de}}$ \\
\hline
\end{tabular}

${ }^{\mathrm{a} C}$ Compared with the miRNA-200b inhibitor group, the difference was statistically significant, $\mathrm{P}<0.05 ;{ }^{\mathrm{b}}$ compared with the mimic control, the difference was statistically significant, $\mathrm{P}<0.05$; ${ }^{\mathrm{c}} \mathrm{compared}$ with the blank control, the difference was statistically significant, $\mathrm{P}<0.05$; ${ }^{\mathrm{d}}$ compared with the $24 \mathrm{~h}$ incubation period, the difference was statistically significant, $\mathrm{P}<0.05$; ${ }^{\mathrm{e}}$ compared with the $48 \mathrm{~h}$ incubation period, the difference was statistically significant, $\mathrm{P}<0.05$.

\section{Detection of invasion and migration of $\mathrm{U} 251$ cells by the Transwell method after transfection}

The invasion and migration abilities of U251 cells of each group were detected by the Transwell method. Results showed that the invasion and migration of U251 cells transfected with the miRNA-200b inhibitor were significantly enhanced compared to those of the control (Table 4), while the invasion and migration of U251 cells transfected with the miRNA-200b mimic was significantly decreased $(\mathrm{P}<0.05)$ (Table 4). Results are shown in Figure 2.

Table 4. Invasion and migration of U251 cells after transfection.

\begin{tabular}{l|c|c|c|c}
\hline & miRNA-200b mimic & miRNA-200b inhibitor & Mimic control & Blank control \\
\hline Invasion & $10.8 \pm 4.7^{\mathrm{abc}}$ & $37.4 \pm 8.6^{\mathrm{bc}}$ & $20.4 \pm 5.8$ & $21.5 \pm 6.5$ \\
\hline Migration & $8.2 \pm 2.1^{\mathrm{abc}}$ & $31.3 \pm 7.4^{\mathrm{bc}}$ & $18.6 \pm 4.1$ & $19.2 \pm 4.3$ \\
\hline
\end{tabular}

${ }^{\mathrm{a}}$ Compared with the miRNA-200b inhibitor group, $\mathrm{P}<0.05$; ${ }^{\mathrm{b}}$ compared with the mimic control group, $\mathrm{P}<0.05$; $\mathrm{c}$ : Compared with the blank control group, $\mathrm{P}<0.05$.

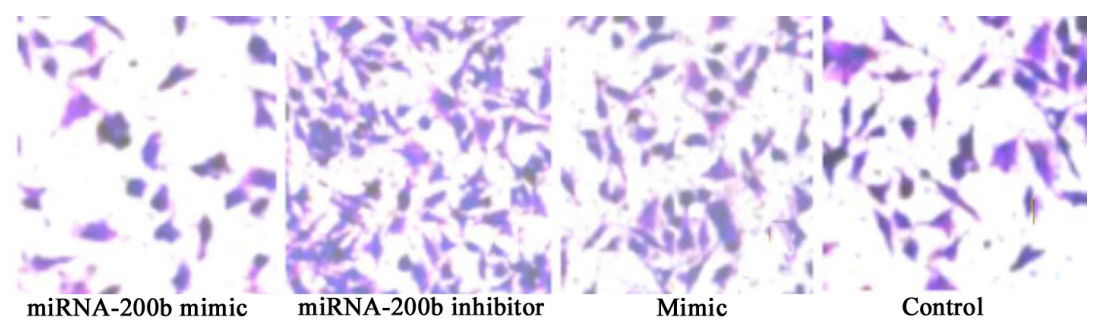

Figure 2. Detection of invasion and migration of U251 cells by the Transwell method after transfection.

Genetics and Molecular Research 16 (1): gmr16019281 


\section{DISCUSSION}

Glioma is a common malignant tumor of the nervous system with high incidence and relapse rates and metastasis potentials (Sun et al., 2013; Ahmed et al., 2014). Surgery, radiotherapy, and chemotherapy are common glioma treatment strategies used in clinics. However, the survival of patients is short with a median survival period of 9-12 months (Stupp et al., 2005). MiRNA is an endogenous non-coding single stranded type of RNA that can partially or completely bind to the nucleotide sequence of the 3'-UTR of target mRNA, leading to the degradation of target mRNA, blockage of the translation process, as well as inhibition of gene expression (Kurashige et al., 2012). Several miRNAs have been found to be involved in the development of gliomas, such as miR-29a, miR-29c, miR-195, miR-200a, miR-181a, miR-181b, miR-26a, and miR-218 (Xia et al., 2010; Feng et al., 2012). MiR-200 family members such as miR-200b/c/429 and miR-200a/141 can regulate cell cycle, affect the differentiation and apoptosis of tumor cells, and participate in the occurrence and development of malignant tumors (Korpal and Kang, 2008). Previous studies have shown that $m i R-200$ is a potential tumor suppressor gene that may have inhibitory effects on the growth of gliomas (Mongroo and Rustgi, 2010).

In the present study, the human malignant glioma U251 cell line was cultured conventionally to be used for the study. MiRNA-200b mimics, miRNA-200b inhibitor, and mimic control were transfected into U251 cells, and the expression of miRNA-200b and CD113 was detected by RT-PCR in the transfected cells. Compared to those in the miRNA-200b inhibitor, mimic control, and blank control groups, the miRNA-200b mimic group displayed increased expression of miRNA-200b and decreased expression of CD133 in a time-dependent manner. However, the miRNA-200b inhibitor group presented significantly reduced miRNA$200 \mathrm{~b}$ expression and increased $C D 133$ mRNA expression. The results demonstrated that there was imbalanced expression of miRNA-200b and CD133 in the glioma cell line U251. In addition, the expression levels of $C D 133$ were decreased in the U251 cell line after miRNA$200 \mathrm{~b}$ transfection, suggesting that miRNA-200b has certain inhibitory effects on CD133 expression. In order to investigate the association between miRNA-200b and CD133, the luciferase reporter assay was performed. Results showed that luciferase activity of the U251 cell line was decreased after co-transfection with the 3'-UTR of CD133 and miRNA-200b mimic, indicating that miRNA-200b negatively regulates the expression of CD133. CD133 is a glycoprotein with 5 transmembrane domains, comprising 865 amino acids (O'Brien et al., 2007). It has been confirmed that tumors in cancers such as gastric cancer, liver cancer, colorectal cancer, etc., have the CD133 phenotype, suggesting that CD133 may be enriched on the surface of cancer stem cells, resulting in a broad spectrum of markers (Welte et al., 2013; Wen et al., 2013; Arndt et al., 2013).

In the present study, the proliferation activity of U251 cells was also measured. Compared to those in the miRNA-200b inhibitor, mimic control, and blank control groups, the OD values and proliferation ratios were significantly decreased in the miRNA-200b mimic group and increased gradually in the miRNA-509-5p inhibitor group in a timedependent manner. Additionally, the Transwell method was used to detect the invasion and migration of U251 cells in each group. Results showed that invasion and migration were markedly enhanced in the miRNA-200b inhibitor transfected U251 cell line and significantly decreased in the miRNA-200b mimic transfected U251 cell line, indicating that the expression levels of miRNA-200b could inhibit the invasion and migration of U251 cells. These results

Genetics and Molecular Research 16 (1): gmr16019281 
were consistent with results obtained in previous studies (Shimono et al., 2009; Zhao et al., 2014). However, the exact mechanism behind the function of miRNA-200b in the biological behavior of glioma cells was not investigated in our study and is the main study limitation. The mechanism needs to be explored in further studies.

In conclusion, our study demonstrated that miRNA-200b negatively regulates CD133 expression by binding to the 3'-UTR of CD133. Moreover, miRNA-200b inhibited the proliferation, invasion, and migration activities of human glioma cells, suggesting that it might be involved in the occurrence and development of gliomas. Therapeutically targeting miRNA-200b might be beneficial in the prophylaxis and treatment of glioma.

\title{
Conflicts of interest
}

The authors declare no conflict of interest.

\section{ACKNOWLEDGMENTS}

\author{
Research supported by the Natural Science Foundation of Shandong Province \\ (\#ZR2014HM004).
}

\section{REFERENCES}

Arndt K, Grinenko T, Mende N, Reichert D, et al. (2013). CD133 is a modifier of hematopoietic progenitor frequencies but is dispensable for the maintenance of mouse hematopoietic stem cells. Proc. Natl. Acad. Sci. USA 110: 5582-5587. http://dx.doi.org/10.1073/pnas.1215438110

Ahmed R, Oborski MJ, Hwang M, Lieberman FS, et al. (2014). Malignant gliomas: current perspectives in diagnosis, treatment, and early response assessment using advanced quantitative imaging methods. Cancer Manag. Res. 6: 149-170.

Brandsma D, Stalpers L, Taal W, Sminia P, etal. (2008). Clinical features, mechanisms, and management of pseudoprogression in malignant gliomas. Lancet Oncol. 9: 453-461. http://dx.doi.org/10.1016/S1470-2045(08)70125-6

Feng B, Wang R and Chen LB (2012). Review of miR-200b and cancer chemosensitivity. Biomed. Pharmacother. 66: 397-402. http://dx.doi.org/10.1016/j.biopha.2012.06.002

Korpal M and Kang Y (2008). The emerging role of miR-200 family of microRNAs in epithelial-mesenchymal transition and cancer metastasis. RNA Biol. 5: 115-119. http://dx.doi.org/10.4161/rna.5.3.6558

Kurashige J, Kamohara H, Watanabe M, Hiyoshi Y, et al. (2012). MicroRNA-200b regulates cell proliferation, invasion, and migration by directly targeting ZEB2 in gastric carcinoma. Ann. Surg. Oncol. 19 (Suppl 3): S656-S664. http:// dx.doi.org/10.1245/s10434-012-2217-6

Lei L and Canoll P (2011). MADM gives new insights into gliomagenesis. J. Mol. Cell Biol. 3: 273-275. http://dx.doi. org $10.1093 / \mathrm{jmcb} / \mathrm{mjr} 023$

Li MY, Pan SR and Qiu AY (2016). Roles of microRNA-221/222 in type 2 diabetic patients with post-menopausal breast cancer. Genet. Mol. Res. 15: 15.

Mongroo PS and Rustgi AK (2010). The role of the miR-200 family in epithelial-mesenchymal transition. Cancer Biol. Ther. 10: 219-222. http://dx.doi.org/10.4161/cbt.10.3.12548

O'Brien CA, Pollett A, Gallinger S and Dick JE (2007). A human colon cancer cell capable of initiating tumour growth in immunodeficient mice. Nature 445: 106-110. http://dx.doi.org/10.1038/nature05372

Shimono Y, Zabala M, Cho RW, Lobo N, et al. (2009). Downregulation of miRNA-200c links breast cancer stem cells with normal stem cells. Cell 138: 592-603. http://dx.doi.org/10.1016/j.cell.2009.07.011

Stupp R, Mason WP, van den Bent MJ, Weller M, et al.; European Organisation for Research and Treatment of Cancer Brain Tumor and Radiotherapy Groups; National Cancer Institute of Canada Clinical Trials Group (2005). Radiotherapy plus concomitant and adjuvant temozolomide for glioblastoma. N. Engl. J. Med. 352: 987-996. http:// dx.doi.org/10.1056/NEJMoa043330

Sun J, Guo M, Pang H, Qi J, et al. (2013). Treatment of malignant glioma using hyperthermia. Neural Regen. Res. 8: $2775-2782$.

Genetics and Molecular Research 16 (1): gmr16019281 
Tabatabai G and Weller M (2011). Glioblastoma stem cells. Cell Tissue Res. 343: 459-465. http://dx.doi.org/10.1007/ $\underline{\mathrm{s} 00441-010-1123-0}$

Wang XX, Ge SJ, Wang XL, Jiang LX, et al. (2016). miR-218 tissue expression level is associated with aggressive progression of gastric cancer. Genet. Mol. Res. 15: gmr.15027521.

Wu JS, Zhang J, Zhuang DX, Yao CJ, et al. (2011). Current status of cerebral glioma surgery in China. Chin. Med. J. (Engl.) 124: 2569-2577.

Welte Y, Davies C, Schäfer R and Regenbrecht CR (2013). Patient derived cell culture and isolation of CD133+ putative cancer stem cells from melanoma. J. Vis. Exp. 13: e50200.

Wen L, Chen XZ, Yang K, Chen ZX, et al. (2013). Prognostic value of cancer stem cell marker CD133 expression in gastric cancer: a systematic review. PLoS One 8: e59154. http://dx.doi.org/10.1371/journal.pone.0059154

Xia W, Li J, Chen L, Huang B, et al. (2010). MicroRNA-200b regulates cyclin D1 expression and promotes S-phase entry by targeting RND3 in HeLa cells. Mol. Cell. Biochem. 344: 261-266. http://dx.doi.org/10.1007/s11010-010-0550-2

Yamamoto T, Nakai K and Matsumura A (2008). [Neutron capture therapy for glioblastoma]. No Shinkei Geka 36: 293302.

Zhao WJ, Yang L and He HJ (2014). miR-200b suppresses proliferation of glioma and its stem cells by targeting CD133. Tumor 34: 231-237.

Genetics and Molecular Research 16 (1): gmr16019281 